\title{
O INFAMILIAR [DAS UNHEIMLICHE], EDIÇÃO COMEMORATIVA BILÍNGUE (1919-2019)
}

Lenice Alves Soares (UERJ)

Recebido em 14 set 2019. Lenice Alves Soares é Mestranda em Teoria Aprovado em 21 set 2019. da Literatura e Literatura Comparada pela UERJ, Psicanalista e Especialista em Psicologia Transdisciplinar Holística pela FSJT e UNIPAZ-Rio (2015), Especialista no Ensino de Alemão como Língua Estrangeira pela UFBA e Universidade de Kassel-Alemanha (2005), Especialista em Língua e Literatura alemã pela UFRJ (2000) e é Licenciada em Letras Português-Alemão pela UFF (1992). Atua como professora de alemão (ICG) e Terapeuta holística (CRT 49333). Lattes: http://lattes.cnpq. br/3215484032184593 E-mail: leniceicg@terra.com.br 
Foi lançada, em abril de 2019, uma edição comemorativa de cem anos, dessa vez bilíngue, do famoso ensaio de Sigmund Freud, Das Unheimliche. Essa edição faz parte da coleção Obras incompletas de Sigmund Freud, da Editora Autêntica, de Belo Horizonte, com organização e apresentação de Gilson Iannini e Pedro Heliodoro Tavares.

A edição, além de conter o famoso

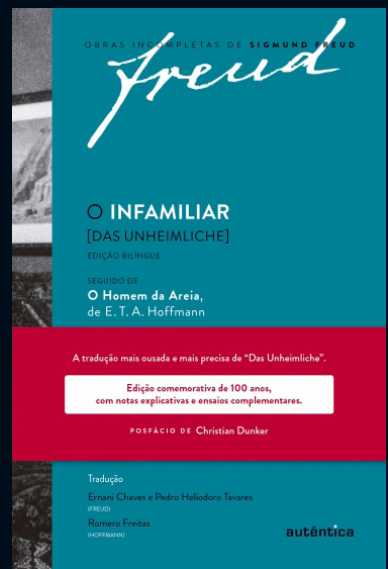
ensaio, que em português ficou inicialmente conhecido como $O$ estranho, vindo, posteriormente, a ser traduzido por $O$ inquietante, amplamente utilizado na área dos estudos literários, traz, também, 0 conto "O homem da areia", de E. T. A. Hoffmann, referido por Freud ao longo de seu texto. Assim, o trabalho do leitor, interessado em recorrer ao conto utilizado como base para ilustrar grande parte dos estudos freudianos sobre o tema, fica facilitado. Além desses dois textos, ambos com nova tradução para o português diretamente do original alemão, a edição traz, ainda, três outros curtos textos do pai da psicanálise, com temáticas afins ao ensaio principal, bem como três trabalhos de especialistas brasileiros sobre o tema e um posfácio sobre Hoffmann.

Gilson lannini, editor e idealizador da coleção, é doutor em filosofia e psicanalista, com pesquisa de pós-doutorado sobre as relações entre ciência e literatura em Freud, e, atualmente, professor do Departamento de Psicologia da Universidade Federal de Minas Gerais (UFMG), onde leciona Teoria Psicanalítica. Pedro Heliodoro Tavares, coordenador de tradução e revisor técnico da 
coleção, é doutor em literatura pela Universidade Federal de Santa Catarina (UFSC), onde atua como professor na área de alemão, e, também, doutor em psicanálise e psicopatologia com pesquisa de pós-doutorado sobre as traduções da obra de Freud. Dessa maneira, constatamos que os organizadores da coleção transitam entre diversos campos do saber, como psicanálise, filosofia, literatura, língua e tradução, o que enriquece o trabalho para estudiosos de diferentes áreas de interesse.

Na apresentação intitulada "Freud e o infamiliar" é sintetizado o percurso feito por Freud em seu ensaio com a "palavra-conceito" (Begriffswort) unheimlich sendo discutida. O autor perpassa várias áreas, partindo de uma "intrincada análise lexicológica" da palavra, mobilizando uma "trama de referências que parte da ciência, passa pela filologia e pela estética, indo até a literatura fantástica, sem nunca perder de vista o que interessa ao psicanalista" (IANNINI; TAVARES, 2019, p.7). Dessa forma,

[n]um movimento às vezes vertiginoso, Freud se apropria de uma palavra de uso relativamente comum em alemão (pelo menos em seu uso adjetivo-adverbial), empresta-Ihe um estatuto conceitual, transporta-a por variadas searas linguísticas e filosóficas, examina a experiência literária que melhor a engendra, escrutina a vivência real que ela recorta, para, ao final, devolver a palavra à língua, mas desta vez com o selo perene da psicanálise. $(2019$, p.7)

lannini e Tavares enfatizam a seguir a mudança que a palavra unheimlich sofre, assim como o que ela designa, a partir da publicação desse ensaio em 1919, ganhando importância onde quer que a psicanálise seja estudada e praticada. Segundo eles: 
Definitivamente, a análise empreendida por Freud modifica não apenas a língua alemã, acrescentando um sentido e um emprego inauditos, mas ainda exporta para todas as línguas através das quais a psicanálise se difundiu um significante novo e incômodo, um vocábulo, a rigor, intraduzível. (2019, p.8)

Adiante, é tematizada a dificuldade de tradução da palavra que dá título ao ensaio nas diversas línguas para as quais foi traduzido, com seus respectivos exemplos e soluções em francês, espanhol, italiano, inglês e português. lannini e Tavares justificam a necessidade de uma nova tradução deste importante ensaio para a língua portuguesa, já que "o intraduzível não é o que não pode ser traduzido, mas o que não cessa de (não) traduzir" (CASSIN, 2018, p.17 Apud IANNINI; TAVARES, 2019, p.8). "Infamiliar" foi, então, o neologismo escolhido como solução de tradução para essa edição, porque melhor expressa, em português, "tanto do ponto de vista semântico quanto do morfológico, o que está em jogo na palavra-conceito Unheimliche em seus usos por Freud". Isso aconteceria:

não porque "infamiliar" expresse o "mesmo" conteúdo semântico do original alemão ou porque se situe numa rede conceitual "equivalente", mas justamente pela razão inversa. O "infamiliar" mostra que o muro entre as línguas não é intransponível, mas também que a passagem de uma língua a outra exige um certo forçamento. O "infamiliar" não é, neste sentido, resultado da fidelidade à língua de partida, mas o vir à tona da infidelidade que tornou possível a transposição do hiato entre as línguas. É uma marca visível da impossibilidade da tradução perfeita. $(2019$, p.9) 
Além do reconhecimento dessa impossibilidade de tradução perfeita, que leva à opção por uma "tradução direta" do vocábulo do alemão para o português, a ambiguidade inerente à palavra "familiar" foi outro aspecto "em favor dessa intradução", afirmam os apresentadores. Quando falamos em português, por exemplo, "isso me parece familiar", ao mesmo tempo queremos dizer "mas me é estranho", ou "não familiar," ou "infamiliar", ou, ainda, "angustiante", por não conseguirmos entender esse sentimento contraditório que nos toma. Vale lembrar que essa ambiguidade é tematizada pelo próprio Freud no referido ensaio. Assim, tanto em alemão quanto em português, existe esse caráter ambíguo no interior da palavra, pois,

[n]esse aspecto particular, "familiar" assemelhase bastante ao alemão heimlich, que designa algo bastante familiar, mas que pode também abrigar seu sentido antitético. $O$ unheimlich é uma negação que se sobrepõe ao heimlich apreendido tanto positiva quanto negativamente: é, portanto, uma reduplicação dessa negação, que acentua seu caráter angustiante e assustador. A palavra em português que melhor desempenha esse aspecto parece ser "infamiliar": do mesmo modo, ela acrescenta uma negação a uma palavra que abriga tanto o sentido positivo de algo que conhecemos e reconhecemos quanto o sentido negativo de algo que desconhecemos. É claro que o original alemão guarda um núcleo angustiante e aterrorizante que "familiar" não abriga, pelo menos em seu uso cotidiano. (2019, p.10)

Mais um aspecto que, segundo os organizadores, fala a favor de uma "não tradução", ou, digamos, de uma "tradução direta" da palavra que dá título ao ensaio, seria o respeito à precisão 
conceitual do autor na elaboração de sua teoria psicanalítica. O conceito do Unheimliche é um dos que mais gera polêmica quanto à sua tradução no âmbito dos estudos psicanalíticos. Não é raro encontrarmos locuções explicativas como "estranho-familiar" ou "inquietante-estranheza", que tentam dar conta tanto da ambiguidade quanto da precisão do conceito. Na tentativa de se aproximar mais do que Freud tentou expressar, faz-se uso aqui de uma só palavra potencialmente equivalente, o "infamiliar".

O psicanalista austríaco ficou conhecido como grande escritor, e uma das características da "escrita freudiana consiste no uso magistral dos recursos da língua alemã, sem nem fundar um novo jargão técnico a partir de línguas clássicas nem propor a criação de novas palavras que se afastassem do léxico já difundido" (2019, p.12). Fazendo jus a essa habilidade e utilizando o próprio recurso de Freud, que é o uso do prefixo de negação un- junto ao adjetivo heimlich, tornando a substantivá-lo (das Unheimliche), chega-se bem próximo do conceito-título com a opção "o infamiliar" para essa nova tradução.

Considerando-se corretas, mas insuficientes, as outras opções de tradução já estabelecidas no Brasil, como "O estranho" (1976) e "O inquietante" (2010), a equipe de agora, após "longo e amadurecido debate", optou por verter "Das Unheimliche" para "O infamiliar". A linha argumentativa desenvolvida por Freud em seu ensaio foi preponderante na escolha por essa terceira opção, como explicam os organizadores:

Trata-se, é verdade, de um caso único no vocabulário freudiano, em que o próprio autor dedica-se exaustivamente, ao longo de todo o 
texto, a uma investigação filológico-lexical acerca de um vocábulo passível de diversas leituras e interpretações. (2019, p.16)

Assim sendo, vários argumentos são apresentados nesse prefácioapresentação que justificam uma terceira tentativa de traduzir o intraduzivel: "Das Unheimliche".

O psicanalista, após um exercício lexical, filológico e até filosófico, chega ao ponto essencial, através do "aparente paradoxo veiculado por uma palavra tão usual da língua" (2019, p.17), que é a confirmação de sua hipótese da divisão psíquica: o prefixo de negação un- é a marca do recalque, cerne da divisão psíquica do ser humano. O elemento negado é o adjetivo heimlich, derivado do substantivo Heim, que significa lar. Portanto, o adjetivo heimlich se refere a tudo o que é relativo ao lar, ou seja, familiar, conhecido ou inerente à privacidade do lar, íntimo, oculto, sigiloso e secreto. Em alemão, esse vocábulo ainda pode se referir também às partes íntimas ou pudendas do corpo humano, ou às partes mais suscetíveis a ferimentos, "evocando indiretamente a angústia da castração" (2019, p.17). Logo, negando aquilo que é familiar e íntimo, mas também secreto e desconhecido, Freud chega ao sentimento do estranho e inquietante, ou à inquietante estranheza, comuns ao recalque da castração que, em alguns momentos da vida, pode vir à tona e nos angustiar: das Unheimliche/ o Infamiliar.

Além disso, o uso de uma única palavra que abarque diversos significados, alguns deles até conflitantes, como "conhecido" e "oculto" ao mesmo tempo, é um recurso muito comum encontrado no processo onírico, muito caro a Freud, que é a condensação (Verdichtung). Através desse recurso, assim como no fazer poético 
(Dichtung), com pouco pode-se dizer muito. Lembramos que "a língua alemã concebe a poesia como uma forma de 'adensamento' do dizer" (2019, p.19).

Através de um estudo morfológico-filológico, e até filosófico, do vocábulo em questão, exemplificado, principalmente, pelo conto $O$ homem da areia, de Hoffmann, Freud demonstra sua tese do recalcamento do complexo de castração, fundamental dentro da teoria psicanalítica. Daí se tem que,

[e]m grande parte, a genialidade de nosso autor inegavelmente reside em identificar na linguagem cotidiana e potencialmente acessível algo que nela é difícil de acessar, não por falta de informação ou por barreiras intelectuais, mas, sobretudo, por causa dos conflitos psíquicos ali enredados. [...] Esse texto que o leitor tem diante de si é uma das mais ricas demonstrações de como a psicanálise opera com sua mais fundamental ferramenta: a língua cotidiana, com suas camadas e sua história. Aqui Freud demonstra de modo inequívoco como se entrelaçam na própria escrita os registros teórico e estético, como a linguagem científica e literária se interpenetram, ou ainda como o vivido e o fantasiado tecem relações complexas. $(2019$, p.21)

lannini e Tavares nos remetem, então, aos três textos de Freud que foram escolhidos para acompanhar o ensaio principal da edição por dialogarem direta ou indiretamente com ele: “E. T. A. Hoffmann sobre a função da consciência", de 1919, "Sobre o sentido antitético das palavras primitivas", de 1910 e "A negação", de 1925.

O curtíssimo "E. T. A. Hoffmann sobre a função da consciência” (1919), com tradução de Pedro Heliodoro Tavares, nada mais é do que a transcrição de uma passagem de Os elixires do Diabo, 
de Hoffmann, publicado entre 1815 e 1816, e que Freud chama de romance "rico em magistrais figurações de estados mentais patológicos" (2019, p.127). Nesse trecho, uma das personagens compara a "especial função mental chamada de consciência" à "execrável atividade de um maldito fiscal - oficial aduaneiro", que impede a saída de produtos de um país.

É impressionante como o escritor alemão expressa, de forma literária, o que vai constituir a base das pesquisas do médico e psicanalista austríaco quase cem anos depois: a consciência (Bewusstsein) humana e seu funcionamento, ou, dito de outra forma, o inconsciente (Unbewusstsein) humano e seu funcionamento.

Em "Sobre o sentido antitético das palavras primitivas" (Über den Gegensinn der Urworte), publicado primeiramente num anuário psicanalítico de 1910, traduzido por Maria Rita Salzano Moraes na atual edição, Freud também parte, como em Das Unheimliche, de reflexões linguístico-filológicas para uma discussão essencialmente psicanalítica sobre o mecanismo do inconsciente e dos sonhos.

O texto, uma espécie de resenha ao trabalho de mesmo nome do filólogo comparatista alemão Carl Abel, de 1884, fornece a Freud o fundamento linguístico da tese de que a negação não opera no inconsciente. Ele acrescenta uma nota sobre o tema na terceira edição de A interpretação dos sonhos, de 1911, quando afirma que o sonho não conhece nem a oposição (Gegensatz), nem a contradição (Widerspruch), chamando a atenção para palavras que expressam, originariamente, um par de opostos de uma só vez, ao invés de servirem a um significado polarizado. Um exemplo disso é sacer, em latim, que significa tanto sagrado quanto maldito, assim 
como heimlich, que, em alemão, significa doméstico e familiar e, ao mesmo tempo, secreto e desconhecido, portanto, infamiliar.

Assim, o sonho prescindiria da negação (Verneinung) e expressaria elementos opostos por meio dos mesmos recursos figurativos, 0 que, segundo Freud, já era sabido pelos intérpretes de sonhos da Antiguidade, que teriam feito "extenso uso da suposição de que uma coisa no sonho pode significar seu contrário" (2019, p.129).

Freud conclui seu curto, mas denso texto sobre a importância do sentido antitético das palavras na teoria a respeito do trabalho do sonho da seguinte forma:

Na concordância entre a peculiaridade do trabalho do sonho destacada no início e a prática descoberta pelo pesquisador nas línguas mais antigas, podemos ver uma confirmação da nossa concepção sobre o caráter regressivo, arcaico da expressão dos pensamentos no sonho. E a nós, psiquiatras [...], impõe-se como uma suposição incontestável o fato de que entenderíamos melhor a linguagem do sonho e o traduziríamos com mais facilidade se soubéssemos mais sobre o desenvolvimento da linguagem. (2019, p.137)

Percebe-se claramente que Freud desenvolveu e ampliou as ideias sobre o sentido antitético das palavras, expostas nesse texto de 1910, em seu ensaio Das Unheimliche, pois o mesmo vale para a palavra que dá título ao famoso ensaio.

Já em “A negação" (Die Verneinung), publicado em 1925, e aqui igualmente traduzido por Maria Rita Salzano Moraes, Freud fala da negação como recusa (Abweisung) ou recalcamento (Verdrängung) inconsciente. Assim, na clínica, quando o paciente nega algum conteúdo, na verdade, é como se ele tivesse dito o contrário, pois 
"na interpretação, tomamos a liberdade de ignorar a negação e extrair o conteúdo puro da ideia que ocorreu" (2019, p.141). O conteúdo recalcado, ou seja, o que foi negado, servirá como via de acesso ao inconsciente, e a negação, por sua vez, é a via de acesso ao material recalcado.

Nesse trabalho, partindo da tese de que aquilo que é negado é o recalcado, Freud desenvolve suas ideias a respeito da função do juízo (Urteilsfunktion), que decide sobre aquilo que o Eu-prazer (Lust-Ich) quer introjetar ou expulsar para fora de si, e também sobre aquilo que o Eu-real (Real-Ich) aceita ou não como realidade externa (prova de realidade). Assim, escreve Freud:

O estudo do juízo nos abre, talvez pela primeira vez, a compreensão [Einsicht] do surgimento de uma função intelectual a partir do jogo das moções pulsionais primárias. O julgar é a continuação objetivada daquilo que originariamente é realizado de acordo com o princípio de prazer: a inclusão no Eu ou a expulsão [Ausstoßung] para fora do Eu. Sua polaridade parece corresponder à oposição dos dois grupos de pulsões supostos por nós. A afirmação [Bejahung] - como substituto da união pertence a Eros; a negação - sucessora da expulsão - pertence à pulsão de destruição. (2019, p.145)

Dessa forma, o texto formaliza e amplia ideias e conceitos psicanalíticos importantes, somente prenunciados em Das Unheimliche, como a importância da negação em relação ao material recalcado, valendo, inclusive, para o prefixo de negação (un-/ in-) como marca do recalcamento na palavra-conceito que dá título ao ensaio. O que serve para a morfologia da palavra será ampliado como o princípio de funcionamento de juízos negativos. 
Com relação aos ensaios complementares que ainda fazem parte dessa edição, vale ressaltar que três deles cumprem a função de comentar e aprofundar o conteúdo do texto $O$ infamiliar, que é o carro chefe do volume, sob diferentes aspectos.

O primeiro deles, "Perder-se em algo que parece plano", situa o ensaio de Freud na história do pensamento estético. O autor, Ernani Chaves (2019), professor da Universidade Federal do Pará (UFPA), além de tradutor de Freud, Friedrich Nietzsche e Walter Benjamin, já desenvolveu pesquisas sobre Michel Foucault e os três autores mencionados anteriormente. Chaves situa o ensaio de Freud, primeiramente, entre seus escritos metapsicológicos sobre o narcisismo, de 1914, e Além do princípio do prazer, de 1920, destacando sua especificidade dentro do pensamento freudiano, principalmente em relação à temática da "compulsão à repetição".

A seguir, compara o referido ensaio com seus outros textos relacionados à arte, afirmando que $O$ infamiliar instaura uma espécie de censura já que, diferentemente de outros textos de Freud ligados à arte, nesse ele não dá ênfase à correlação direta entre a vida e a obra do autor referido, Hoffmann. Além disso, afirma Chaves, o ensaio traz algo novo em relação às análises freudianas anteriores sobre arte, como uma concepção de estética, segundo afirmou o próprio Freud, que não se restringe mais a uma doutrina do belo, assim como um posicionamento diferente, ousado e corajoso de quem está ciente de estar fundando uma maneira nova de abordar a estética. Em sua opinião,

Essa mudança de posição, a meu ver, constitui o aspecto mais importante desse texto, no que se refere ao campo da estética. Quase inteiramente 
indiferente à revolução que as vanguardas estéticas de sua época estavam promovendo, Freud, paradoxalmente, acabou criando um dispositivo interpretativo do qual as vanguardas puderam se aproveitar. (2019, p.155)

Com uma definição original de estética como "teoria das qualidades do nosso sentir", Freud se distancia da associação entre estética e teorias do belo tradicionais de até então, já que $O$ infamiliar ressalta o medo, a angústia e o horror. Essa nova definição reflete não só uma nova maneira de se entender a estética, como também de se entender o ser humano e o mundo que o cerca.

O excelente ensaio de Chaves (2019) situa a importância do texto de Freud não só para a literatura fantástica do século XIX, como também para nova realidade trazida pela Primeira Guerra Mundial e, acima de tudo, para uma nova forma de "perceber" e "sentir" a "realidade". Ele ressalta, ainda, consequências importantes que o texto provoca no âmbito da teoria da literatura e das relações entre estética e política, sua "possibilidade de instaurar novos discursos", lembrando Foucault, e a necessidade do "trabalho de elaboração do passado", lembrando Adorno e Horkheimer.

O segundo ensaio complementar, "O infamiliar, mais além do sublime", assinado por Guilherme Massara Rocha e Gilson lannini, ambos psicanalistas, doutores em filosofia e professores do Departamento de Psicologia da UFMG, destaca aspectos metapsicológicos do texto de Freud, acrescentando ao debate estético o horizonte ético da clínica psicanalítica.

Inicialmente, os autores situam a psicanálise como uma "obra de resistência" (ROCHA; IANNINI, 2019) no contexto de miséria e 
destruição do final da Primeira Grande Guerra, lembrando que, justamente nesta época, a potência da morte é incorporada aos pressupostos da doutrina freudiana. Segundo eles,

A pulsão de morte freudiana, da qual o presente artigo é uma espécie de prelúdio, foi objeto de extensas reelaborações que usualmente buscaram desdobrar seu impacto para a clínica da psicanálise, bem como para a modulação das contribuições analíticas para investigações acerca do campo social. Mas o fato é que naquilo em que esse conceito se forja a partir de um certo trabalho do negativo [...], "Das Unheimliche" talvez seja o texto que nos coloca diante de certas vicissitudes estéticas da pulsão de morte. O que nos coloca diante da difícil questão das relações entre o Unheimlich e a sublimação. (2019, p.175-176)

Os autores lembram que o prometido artigo sobre a sublimação nunca veio a lume e que o fato de $O$ infamiliar ter sido "redigido no vácuo deixado pelo inexistente artigo" suscita a questão "acerca das relações de continuidade e descontinuidade, concordância e discordância, entre o Unheimlich e o sublime" (2019, p.176), questão esta que divide a literatura especializada em dois polos. De um lado, a crítica literária norte-americana, liderada por Harold Bloom, que vê o ensaio de Freud como uma contribuição para a estética do sublime. De outro, aqueles que estão mais preocupados em mostrar as "descontinuidades e discordâncias entre a perspectiva freudiana do Unheimlich e a tradição do sublime" (2019, p.177).

Outra questão levantada por Rocha e lannini é a proposição de que o sublime angustia. Esse aspecto já foi debatido pela tradição do 
idealismo alemão, e desbravado por Freud com sua metapsicologia em seu ensaio. Escolhendo Hoffmann e o conto "O homem da areia" para "delimitar com maior precisão a especificidade do fenômeno ali abordado" (2019, p.179), Freud se conecta para sempre com a literatura fantástica e as teorias que a fundamentam. Segundo os autores, o texto de Freud aborda um vasto material, mas, diferentemente de seus outros textos, sem muita clareza e delimitação. Na opinião deles:

De forma curiosamente inquietante, "O infamiliar" é um texto fraturado, reiteradas vezes interrompido bruscamente, e que parece sonegar ao leitor um norte, um fio condutor ou mesmo um apoio acerca de seus propósitos fundamentais, produzindo no leitor o efeito que ele próprio descreve. (2019, p.181)

Rocha e lannini abordam, ainda, a ambivalência da palavra, o paradoxo que evoca o sublime, em que os eventos contrários coexistem estranhamente para além do sublime. O elemento fantástico, que promove uma descontinuidade no encadeamento lógico de uma narrativa e evoca a sensação do infamiliar, também é abordado, assim como o tema do duplo e da fragmentação, que remetem à angústia da castração. Os autores percorrem o texto de Freud, comentando e pontuando questões relevantes, e o designam como multifacetado, no qual, questões como ética, estética, clínica e metapsicologia se interpolam e se dissociam.

O terceiro e mais extenso ensaio complementar intitula-se "Animismo e indeterminação em 'Das Unheimliche", cujo autor, Christian Ingo Lenz Dunker (2019), psicanalista e professor titular do Departamento de Psicologia Clínica da Universidade de São 
Paulo (USP), insere o texto de Freud no debate contemporâneo sobre o animismo, jogando uma nova luz sobre este em relação ao totemismo.

Em primeiro lugar, o autor situa o ensaio de Freud numa "verdadeira encruzilhada de três caminhos no interior da obra freudiana" (DUNKER, 2019, p.x), ao observar que:

Ele retoma e ajusta contas com a antropologia expressa em Totem e tabu, cujo problema central é o papel do totemismo e do animismo. Ele também antecipa a nova teoria das pulsões, marcada pela acentuação do papel da repetição e da angústia, que virá à luz, um ano depois, em Além do princípio do prazer. Finalmente, ele é um ancestral metodológico do texto sobre "A negação", de 1925, no qual Freud faz a análise discursiva das negações e dos tipos de juízo existencial e valorativo. (2019, p.199)

Dunker lembra que Freud se confrontou com o problema do unheimlich, como ele mesmo coloca em seu texto, durante alguns anos, mesmo antes da redação de Totem e tabu, publicada em 1913, e sua temática - fenômenos mágicos, místicos, semirreligiosos e sobrenaturais - sintetiza questões que ocuparam parte do debate, da colaboração e da dissensão com Carl Gustav Jung. Além de reexaminar o modo animista de pensar, $O$ infamiliar também lançaria "uma interrogação sobre o estatuto da verdade e da realidade em psicanálise, bem como um exemplo maior do exercício da análise lógica das negações" (2019, p.199-200). A seguir, ele traça um panorama sobre o texto e comenta o que chama de "seu imanente problema de tradução" (2019, p.200), elogiando a opção adotada nesta edição e fundamentando sua opinião com elementos da própria teoria psicanalítica. 
Dunker ressalta, ainda, a relação entre totemismo e animismo no texto de Freud. Segundo ele, enquanto em Totem e tabu essas duas estruturas antropológicas são tratadas de forma dissimétricas pelo psicanalista austríaco, já que o totemismo funcionaria como um organizador social necessário nas culturas por ser "uma espécie de matriz arcaica da socialização humana" (2019, p.206), o animismo seria "uma forma provisória e menor de pensamento infantil" (2019, p.206), que deverá ser suplantado com a superação de crenças narcísicas e substituído pela crença na realidade desencantada. Em $O$ infamiliar, isso seria, sob seu ponto de vista, relativizado, uma vez que:

A primazia do totemismo encontra em "O infamiliar" alguns motivos para ser ao menos relativizada. Isso ocorre porque a solidez da experiência identitária, baseada na familiaridade e na convicção de quem somos "nós", é abalada pela problemática do unheimlich. [...] Se o totemismo se caracteriza por manter a ontologia fixa e a epistemologia variável [...], o animismo, especialmente em sua forma perspectivista, baseia-se em um sistema de ontologias móveis ou também chamado de múltiplas naturezas. (2019, p.207)

Com isso, Dunker (2019) nos remete a ideias de alguns antropólogos contemporâneos que não concordam que o animismo seja apenas um capítulo do totemismo, ou um déficit cognitivo que deva ser enfrentado pelo ser humano.

Na terceira parte de seu ensaio, ele volta aos temas do totemismo e do animismo e os desenvolve, mas, dessa vez, exemplificando com questões extraídas do próprio conto "O homem da areia": o duplo e sua relação com o narcisismo e o Supereu; o autômato e o possível déficit de integração simbólica; 
a violação do pacto entre realidade e fantasia e a compulsão à repetição; a incerteza e a permutação do eu. Com esse agrupamento de exemplos, chega à seguinte conclusão:

Este rápido agrupamento dos inúmeros exemplos trazidos no ensaio de Freud mostra que, no fenômeno da infamiliaridade, o totemismo paterno e o animismo narcisista atuam de modo combinado. Eles podem envolver tanto a perda de unidade simbólica do mundo ou do corpo como a perda da experiência de si e a alienação da identidade. Eles podem se associar com a violação de leis simbólicas ou com a intrusão de objetos que perturbam a relação de inclusão e congruência entre realidade e fantasia. (2019, p.213-214)

Ele retoma o tema da negação na última parte do seu ensaio, fazendo analogia com o retorno do recalcado e chamando a atenção para a diferença entre a realidade vivida e a realidade ficcionalliterária. Para o surgimento do fenômeno do infamiliar deve haver o conflito de julgamentos, e isso está ligado tanto à superação de crenças animistas infantis, com a aceitação da maturidade da razão, quanto à entrada no animismo perspectivo, com a realização simbólica e subjetiva da realidade poética. Conforme assevera:

Tudo se passa como se Freud estivesse admitindo a existência de ontologias variáveis, entre a ficção e o documentário, entre o mundo possível e o mundo necessário, sem fixar este último no critério ontológico da ciência. Isso ocorre pela introdução da chave temporal, que inclui o futuro como condição possível para definir um determinado mundo. Essa indeterminação perspectiva envolve a comparação entre gêneros narrativos, como o conto maravilhoso, a literatura romântica de 
horror, mas também a realidade, material ou psíquica. (2019, p.216)

Assim, o ensaio de Dunker suscita questões interessantíssimas para debates, seja no âmbito dos estudos literários, seja no da psicanálise, bem como os outros dois ensaios complementares, todos os três comentando o texto freudiano.

O quarto ensaio complementar, que vem após o conto $O$ homem da areia e serve de posfácio à edição, chama-se "Cidadão de dois mundos" e é dedicado ao contexto estético da literatura de Hoffmann. O autor, Romero Freitas (2019), também responsável por essa nova tradução do conto, é filósofo, especialista em estética e filosofia da arte, e professor no Departamento de Filosofia da Universidade Federal de Ouro Preto (UFOP), além de tradutor de Heinrich Heine e Walter Benjamin.

Freitas divide seu ensaio em quatro partes. Na primeira, delineia um curto, mas interessante, panorama sobre a vida e a obra de Hoffmann, assim como sobre sua recepção à época da publicação na Alemanha, comentando, inclusive, o papel que Goethe teria tido na difusão de uma imagem negativa do autor; na segunda parte, comenta o romantismo singular de Hoffmann e sua recepção fora do solo alemão; na terceira parte, apresenta Hoffmann como um herético realista, representante da crítica ao romantismo, o que pode ser observado, inclusive, em $O$ homem da areia; na quarta parte, ressalta o ceticismo e o modernismo de Hoffmann, "um escritor singular, quase uma impossibilidade lógica: ao mesmo tempo cético, satírico, fantástico e realista" (2019, p.271). Exemplificando com conteúdos de $O$ homem da areia e fatos da vida do autor, Freitas defende que o segredo de Hoffmann estaria no contraste. 
Essa edição comemorativa nos presenteia, portanto, não só com duas novas traduções de dois clássicos - $O$ infamiliar, de Freud, e $O$ homem da areia, de Hoffmann -, como também com ricos ensaios complementares que nos incitam a reler essas obras, tão importantes para os estudos literários e para a psicanálise, jogando sobre elas um novo olhar e acendendo novos e inesgotáveis debates.

Não pretendo tecer comentários a respeito das traduções, pois ambas, sem sombra de dúvida, são de alta qualidade. Como toda tradução, elas apresentam sua originalidade e sua arte e técnica, mas também pontos específicos dos quais podemos discordar ou os quais poderíamos, ao menos, questionar. Cada leitor está convidado a se lançar nessa nova leitura e tirar suas próprias conclusões, de acordo com seus gostos, tendências, ideias e interesses. Limito-me apenas a transcrever um pequeno trecho de cada uma dessas perenes obras com suas respectivas traduções já conhecidas e as novas, assim como o original em alemão em nota de rodapé. A intenção é que cada leitor possa ter uma provinha e se sinta motivado a degustar um pouco mais.

A seguir, o trecho inicial de $O$ homem da areia ${ }^{1}$, de Hoffmann, primeiramente com a já conhecida tradução de Ary Quintella 1

Der Sandmann. Nathanael an Lothar: Gewiss seid ihr alle voll Unruhe, dass ich so lange - lange nicht geschrieben. Mutter zürnt wohl, und Clara mag glauben, ich lebe hier in Saus und Braus und vergesse mein holdes Engelsbild, so tief mir in Herz und Sinn eingeprägt, ganz und gar. - Dem ist aber nicht so; täglich und stündlich gedenke ich eurer aller und in süßen Träumen geht meines holden Clärchens freundliche Gestalt vorüber und lächelt mich mit ihren hellen Augen so anmutig an, wie sie wohl pflegte, wenn ich zu euch hineintrat. - Ach wie vermochte ich denn euch zuschreiben, in der zerrissenen Stimmung des Geistes, die mir bisher alle Gedanken verstörte! - Etwas Entsetzliches ist in mein Leben getreten! - Dunkle Ahnungen eines grässlichen mir drohenden Geschicks breiten sich wie schwarze Wolkenschatten über mich aus, undurchdringlich jedem freundlichen Sonnenstrahl. - Nun soll ich dir sagen, was mir widerfuhr. Ich muss es, das sehe ich ein, aber nur es denkend, lacht es wie toll aus mir heraus. - Ach mein herzlieber Lothar! wie fange ich es denn an, dich nur einigermaßen empfinden zu lassen, dass das, was mir vor einigen Tagen geschah, denn wirklich mein Leben so feindlich zerstören konnte! Wärst du nur hier, so könntest du selbst schauen;aber jetzt hältst du mich gewiss für einen aberwitzigen Geisterseher. (HOFFMANN, 2015). 
(HOFFMANN, 2012), da coleção Novelas imortais, com organização e apresentação de Fernando Sabino, seguido da nova tradução de Freitas (HOFFMANN, 2019):

Natanael para Lothar

Vocês devem estar bem preocupados, pois não Ihes escrevo há muito tempo. Minha mãe deve estar zangada. Clara deve estar pensando que vivo num turbilhão de prazeres e que esqueci inteiramente sua figura angelical e doce, impressa de forma profunda em meu coração e em minha mente. Mas não é nada disso. Todos os dias, a cada hora, penso em vocês e a encantadora figura de Clara aparece e torna a aparecer em meus devaneios. Seus olhos límpidos sorriem para mim com tanta graça quanto antigamente, assim que eu entrava em casa. Mas como poderia Ihes escrever com esta violenta perturbação de espírito que me destrói a mente? Uma coisa horrível aconteceu comigo! Pressentimentos inquietantes, terríveis, ameaçadores, passam-me pela cabeça como nuvens negras no temporal, impenetráveis aos raios alegres da amizade. Você me pede que the conte o que me aconteceu. É necessário que eu conte, bem sei. Mas só de pensar nisso começo a $r$ ir como demente. Ah, meu querido Lothar! Como conseguiria fazer você entender, apenas um pouquinho, que o acontecido há poucos dias pode complicar terrivelmente a minha vida? Se - pelo menos - você estivesse aqui, poderia ver com seus próprios olhos. Mas, tenho certeza, vai pensar que sou um louco visionário. (HOFFMANN, 2012)

Nathanael a Lothar

Certamente vocês estão todos muito apreensivos porque eu não escrevo há tanto - tanto tempo. Mamãe deve estar furiosa, e Clara deve achar 
que vivo aqui no bem-bom e que esqueço por completo a minha encantadora imagem angelical, tão profundamente gravada no meu coração e no meu pensamento. Mas não é nada disso; todo dia e a toda hora eu penso em vocês todos, e a figura amável de minha encantadora Clarinha aparece em doces sonhos e me sorri com seus olhos claros tão graciosamente como ela costumava sorrir quando eu voltava até vocês. Ah, mas como eu poderia escrever-lhes com a disposição de espírito que constantemente me perturba todos os pensamentos! - Uma coisa terrível aconteceu na minha vida! - Pressentimentos sombrios de um destino horroroso e ameaçador se espalham sobre mim como sombras de nuvens negras, impenetráveis a qualquer aprazível raio de sol. - Agora eu devo contar-Ihe o que me aconteceu. Preciso fazer isso, eu vejo, mas só de pensá-lo explode em mim um riso enlouquecido. Ah, meu estimado Lothar! Como posso fazer com que você sinta, pelo menos de alguma forma, que aquilo que me sucedeu há alguns dias pôde destruir a minha vida de modo tão funesto! Se ao menos você estivesse aqui, poderia ver por si próprio; mas agora decerto você me toma por um disparatado que vê fantasmas. (2019, p.221)

Agora, um excerto do nosso texto principal, Das Unheimliche, de Freud. Nesse trecho, o autor afirma ser o infamiliar um tema negligenciado na literatura específica sobre a estética e indaga a que ele estaria relacionado. A primeira, e mais antiga tradução para o português, da editora Imago, de 1976, tem tradução de Jayme Salomão a partir das obras completas de Freud em inglês (Standard Edition); a segunda, da editora Companhia das Letras, de 2010, com tradução de Paulo César Lima de Souza, 
foi feita diretamente da edição em alemão; a terceira, da edição comemorativa, assinada por Chaves e Tavares, também é feita diretamente do original em alemão²:

O tema do "estranho" é um ramo desse tipo. Relaciona-se indubitavelmente com o que é assustador - com o que provoca medo e horror; certamente, também, a palavra nem sempre é usada num sentido claramente definível, de modo que tende a coincidir com aquilo que desperta o medo em geral. Ainda assim, podemos esperar que esteja presente um núcleo especial de sensibilidade que justificou o uso de um termo conceitual peculiar. Fica-se curioso para saber que núcleo comum é esse que nos permite distinguir como "estranhas" determinadas coisas que estão dentro do campo do que é amedrontador. (FREUD, 1976, p.276 - grifo nosso)

"O inquietante" é um desses domínios. Sem dúvida, relaciona-se ao que é terrível, ao que desperta angústia e horror, e também está claro que o termo não é usado sempre num sentido bem determinado, de modo que geralmente equivale ao angustiante. É lícito esperarmos, no entanto, que exista um núcleo especial [de significado] que justifique o uso de um termo conceitual específico. Gostaríamos de saber que núcleo comum é esse, que talvez permita distinguir um "inquietante" no interior do que é angustiante. (FREUD, 2010, p.329330 - grifo nosso)

2 Ein solches ist das »Unheimliche«. Kein Zweifel, daß es zum Schreckhaften, Angst- und Grauenerregenden gehört, und ebenso sicher ist es, daß dies Wort nicht immer in einem scharf zu bestimmenden Sinne gebraucht wird, so daß es eben meist mit dem Angsterregenden überhaupt zusammenfällt. Aber man darf doch erwarten, daß ein besonderer Kern vorhanden ist, der die Verwendung eines besonderen Begriffswortes rechtfertigt. Man möchte wissen, was dieser gemeinsame Kern ist, der etwa gestattet, innerhalb des Ängstlichen ein »Unheimliches" zu unterscheiden. (FREUD, 2019, p.28 - grifo nosso). 
Algo deste domínio é o "infamiliar". Não há nenhuma dúvida de que ele diz respeito ao aterrorizante, ao que suscita angústia e horror, e, de todo modo, estamos seguros de que essa palavra nem sempre é utilizada num sentido rigoroso, de tal modo que, em geral, coincide com aquilo que angustia. Entretanto, pode-se esperar que exista um determinado núcleo, que justifique a utilização de uma palavra-conceito específica. Gostaríamos de saber o que é esse núcleo comum, que permite diferenciar, no interior do angustiante, algo "infamiliar". (FREUD, 2019, p.29 - grifo nosso)

Estão grifadas as palavras ou termos que mais suscitam problemas e controvérsias no campo psicanalítico, seja em português, seja em outras línguas. Além da nossa palavra-conceito - unheimlich -, que dá título ao ensaio de Freud e que já foi bastante debatida ao longo desta resenha, vale ainda ressaltar que a palavra Angst, que em alemão pode significar tanto medo, quanto angústia, é, especialmente neste contexto, juntamente com seus derivados, de difícil tradução.

Por ser bilíngue, e apresentar o original em alemão na página ao lado da nova proposta de tradução para o português, a edição comemorativa se torna especialmente prática para os estudiosos que dominam as duas línguas. Como em outros de seus textos que dialogam com formas de expressão humana, em Das Unheimliche, especialmente, um objeto literário serve como base argumentativa para Freud. Assim, para os pesquisadores e interessados de diversas áreas, sobretudo da psicanálise e dos estudos literários, o acréscimo do conto de Hoffmann na mesma edição facilita enormemente a pesquisa, pois pode-se recorrer de forma rápida à obra que Freud utilizou como base para suas explanações. Menção especial deve ser feita às valiosas notas que integram essa edição, sobretudo 
àquelas referentes aos textos de Freud, acrescentando que todas as notas do original em alemão foram mantidas.

Como nos esclarecem os organizadores ao final da edição, "a coleção Obras Incompletas de Sigmund Freud não pretende apenas oferecer uma nova tradução, direta do alemão e atenta ao uso dos conceitos pela comunidade psicanalítica brasileira" (2019, p.277). A intenção de "ainda oferecer uma nova maneira de organizar e de tratar os textos" (2019, p.277) é aqui também extremamente atual e de grande relevância, assim como "o tratamento absolutamente singular" (2019, p.277) conferido a cada volume pela equipe multidisciplinar responsável por esse excelente trabalho.

Concluindo, vale ressaltar que a edição comemorativa se destaca, especialmente, pela tentativa de precisão conceitual e rigor filológico, além do cuidado estilístico que faz jus à qualidade e à importância dos escritos de Sigmund Freud, o que é de extrema relevância para estudiosos e interessados de variadas áreas de pesquisa. Com isso, a edição instiga novos debates e contribui para que $O$ infamiliar permaneça sempre atual.

\section{REFERÊNCIAS}

CHAVES, Ernani (2019). "Perder-se em algo que parece plano". In: FREUD, Sigmund. O infamiliar e outros escritos. Obras incompletas de Sigmund Freud. Belo Horizonte: Autêntica, v.8, p.153-172.

DUNKER, Christian Ingo Lenz (2019). "Animismo e indeterminação em 'Das Unheimliche'”. In: FREUD, Sigmund. O infamiliar e outros escritos. Obras incompletas de Sigmund Freud. Belo Horizonte: Autêntica, v.8, p.199-218.

FREITAS, Romero (2019). "Cidadão de dois mundos" (posfácio). In: FREUD, Sigmund. O infamiliar e outros escritos. Obras incompletas de Sigmund Freud. Belo Horizonte: Autêntica, v.8, p.265-273. 
FREUD, Sigmund (1976). "O estranho". In: Obras psicológicas completas de Sigmund Freud. Jayme Salomão (Trad.). Rio de Janeiro: Imago, v.XVII, p.275-314. (2010). "O inquietante". In: Obras completas. Paulo César de Souza (Trad.). São Paulo: Companhia das Letras, v.14, p.329-376.

(2019). “A negação". Maria Rita Salzano Moraes (Trad.). In:

O infamiliar e outros escritos. Obras incompletas de Sigmund Freud. Belo Horizonte: Autêntica, v.8, p.141-150.

(2019). "E. T. A. Hoffmann sobre a função da consciência". Pedro Heliodoro Tavares (Trad.). In: . O infamiliar e outros escritos. Obras incompletas de Sigmund Freud. Belo Horizonte: Autêntica, v.8, p.127.

(2019). "O infamiliar". Ernani Chaves (Trad. e notas) e Pedro Heliodoro Tavares (Trad.). In: . O infamiliar e outros escritos. Obras incompletas de Sigmund Freud. Belo Horizonte: Autêntica, v.8, p.26-125.

(2019). "Sobre o sentido antitético das palavras primitivas". Maria Rita Salzano Moraes (Trad.). In: O infamiliar e outros escritos. Obras incompletas de Sigmund Freud. Belo Horizonte: Autêntica, v.8, p.129-140.

HOFFMANN, E. T. A. (2012). O homem da areia. Ary Quintella (Trad.). Rio de Janeiro: Rocco Digital.

(2015). Der Sandmann. Stuttgart: Reclam.

(2019). "O homem da areia". Romero Freitas (Trad.). In: FREUD, Sigmund. O infamiliar e outros escritos. Obras incompletas de Sigmund Freud. Belo Horizonte: Autêntica, v.8, p.219-264.

IANNINI, Gilson; TAVARES, Pedro Heliodoro (Org.) (2019). "Freud e o infamiliar". In: FREUD, Sigmund. O infamiliar e outros escritos. Obras incompletas de Sigmund Freud. Belo Horizonte: Autêntica, v.8, p.7-25.

(2019). Obras incompletas de Sigmund Freud. In: FREUD, Sigmund. O infamiliar e outros escritos. Obras incompletas de Sigmund Freud. Belo Horizonte: Autêntica, v.8, p.275-277.

ROCHA, Guilherme Massara; IANNINI, Gilson (2019). "O infamiliar, mais além do sublime". In: FREUD, Sigmund. O infamiliar e outros escritos. Obras incompletas de Sigmund Freud. Belo Horizonte: Autêntica, v.8, p.173-198. 